\title{
Analysis of Meaning Types Using Audio-Visual Media in Easy English Video
}

\author{
Nurnaningsih \\ Universitas Veteran Bangun Nusantara \\ Sukoharjo, Indonesia \\ nurnaninx@yahoo.co.id \\ Purwani Indri Astuti \\ Universitas Veteran Bangun Nusantara \\ Sukoharjo, Indonesia \\ indripoespa@gmail.com
}

Veronika Unun Pratiwi

Universitas Veteran Bangun Nusantara

Sukoharjo, Indonesia

pratiwiunun@yahoo.co.id

Aji Reynaldi

Universitas Veteran Bangun Nusantara

Sukoharjo, Indonesia

ajirenalddi@gmail.com

\begin{abstract}
The aim of this research is to describe the meaning types in the Easy English video. This research is a qualitative research because the researcher analyzed the data in written form. The data of the research are interviewee's utterances about what they know about Germany in Easy English video. The data source of the research is the Easy English video: What Do You Know About Germany episode script, that was downloaded from you-tube. The researcher collected the data using documentation and content analysis technique. The researcher found 62 data. It was consisted of 17 conceptual meanings, 8 connotative meanings, 2 social meanings, 19 affective meanings, 5 reflected meanings, 5 collocative meanings, and 6 thematic meanings. The result of this research are the researcher found $27.41 \%$ for conceptual meaning, $12.9 \%$ for connotative meaning, $3.22 \%$ for social meaning, $30.64 \%$ for affective meaning, $8.06 \%$ for reflected meaning, $8.06 \%$ for col-locative meaning, and $9.67 \%$ for thematic meaning.
\end{abstract}

Keywords- audio-visual media, meaning, meaning types, qualitative research semantics, video.

\section{INTRODUCTION}

The word is the basic unit of language, and the building-blocks of language for human to make the sentences or utterances [1]. Utterances which is produced by speaker have their different own meanings and purposes of speaker. Based on Clark and Clark's in [2], there are three major aspects of language. They are phonology, syntax, and semantics. Phonology are the studies of language sounds and their structure. Syntax is the study of the way words combine to form sentences. Semantics are the studies of word and sentences' meaning. So, semantics is the one of study that is related to this research's purposes about discussing utterances' meaning.

Semantics is the study of meaning which is used in order to inform us how to understand about expression of human by language. Based on [3] in book entiled Pengajaran Semantik, that semantics is the study of meaning that discusses about signs which state the meaning, the relation of the meaning with other meanings, and its effect to human and society. The aims are to make a good communication and people can understand what the partner means by his or her utterances. The good communication can be seen from the conversation process which the speaker can consider about choosing sign and language usage in its conversation. So, there is no missunderstanding happens from the listener about the meaning of utterances and the purposes of the utterances can be delivered well by speaker.

There are seven types of meanings which taken from [4] Conceptual meaning is logical, cognitive or denotative content in utterances; Connotative meaning is what communicated by virtue of what language refers to; Social meaning is what commuicated of the social circumtances of language use; Affective meaning is what communicated of the feeling and attitudes of the speaker; Reflected meaning is what communicated through association with another sense of the same expression; Collocative meaning is what communicated through association with words which tend to occur in the environment of another word; Thematic meaning is what communicated by the way in which the message is organized in terms of order and emphasis. It means that every types of meaning has their own role.

In this research, the researcher choses Easy English video as its data source. It was downloaded from Easy Language youtube channel. Actually, there were many video editions in Easy Language channel and the Easy English was the one of them. The researcher choses Easy English because this video had many episodes with various topics which are talked about and a lot of utterances in its interviewing of each episode. Each utterance has its own meaning and the researcher was interested to analyze that case because several utterances had different kinds of meaning types. The researcher expected to find out the types of meaning in utterances were conducted by the interviewee in the video. The researcher also expected to describe about the meaning of found utterances which contained the one of meaning types and find out the meaning types mostly used in that video.

There were some utterances in Easy English video that was found and been the example of research data. They can be seen in the following interviewing:

Interviewer : :If an alien were to land here right now, how would you describe the city of york to them?"

Interviewee : "I am an alien."

Based on interviewing above, the interviewer asked about what the interviewee would describe about York city if interviewee met an alien by saying "If an alien were to land here right now, how would you describe the city of 
york to them?". Then, the interviewee answered it by saying "I am an alien". It indicated that the interviewee's utterances or the answer had affective meaning, because the interviewee's answer was not related to the question purpose. The interviewee was human, not an alien as what he said. He answered it in order to make a joke and laughter. So, we could conclude that the interviewee was the funny person.

Based on the explanation above, the researcher was interested to analyze the meaning types of interviewee's utterances in Easy English video and decided to make study entitled "An Analysis of Meaning Types in Easy English Video"

Based on the background above, the formulation of the problems were: What are the meaning types that found in the Easy English video?

Since the researcher had formulations of the problem, the research got objectives of the study. There were: To classify the meaning types that were found in the Easy English video.

Semantics talks that language's meaning are not only depended on linguistic and structural from the speaker and listener, but also in the context or sign of utterances, such as a number of means like gesture, picture, signals, etc. [5]

Meanwhile, [4] stated that semantics is the study of meaning that is based on mind of human. It is also discussing meaning's relation with other one and its effect to human society [3].

\section{METHODS}

Qualitative research has the natural setting as the direct source of data and researcher is the key instrument. [6] The data of the research are interviewee's utterances about what they know about Germany in Easy English video. The data had been downloaded and presented by the researcher into script form.

The data source of the research is Easy English video: What Do You Know About Germany episode script, that was downloaded from you tube.

In this research, the researcher used two methods. They were internet documentation and content analysis.

The steps of internet documentation in this research were:

1. Connecting laptop with internet connection.

2. Opening browser after laptop is connected.

3. Typing www.youtube.com on the adress bar of browser.

4. Typing "Easy English 5" on youtube search bar.

5. Clicking the video "Easy English 5- What Do You Know About Germany" video.

6. Downloading that video by internet download manager.

The steps of content analysis which were done by the researcher were

1. Watching Easy English video; What Do You Know About Germany episode on laptop.
2. Collecting the data (interviewee's utterances in Easy English video: What Do You Know About Germany episode).

3. Making a note of interviewee's utterances which got from Easy English video: What Do You Know About Germany episode.

4. Classifying the data into seven types of meaning: conceptual meaning, connotative meaning, Social meaning, affective meaning, reflected meaning, collocative meaning, and thematic meaning.

5. Giving coding the data, such as

DN : Data number

Time : T

MT : Meaning Types, that consist of:

$\begin{array}{ll}\text { CONS } & \text { : Conceptual meaning } \\ \text { CONN } & \text { : Connotative meaing } \\ \text { SOC } & \text { : Social meaning } \\ \text { AFF } & \text { : Affective meaning } \\ \text { REFL } & \text { : Reflected meaning } \\ \text { COLL } & : \text { Collocative meaning } \\ \text { THEM } & : \text { Thematic meaning }\end{array}$

For example :

06/03.12/SOC

Note :

06 : Data number 06

03.12 : Time on 03.12

SOC : Type of meaning is social meaning

In a qualitative research, the researcher is the key instrument for his qualitative research.

\section{RESULTS AND DISCUSSION}

In this research, the researcher managed to collect 62 data in the script. It was consisted of 17 conceptual meanings, 8 connotative meanings, 2 social meanings, 19 affective meaning, 5 reflected meaning, 5 collocative meaning, and 6 thematic meaning.

In this research, the researcher would like to discuss the data which were found in the research finding about what the meaning types that found in Easy English video: What Do You Know about Germany episode. The Meaning Types That Were Found in the Easy English Video. Data are not presented completely because it makes the data presentation simpler. The data was consisted of 11 conceptual meanings, 4 connotative meanings, 2 social meanings, 12 affective meaning, 3 reflected meaning, 3 collocative meaning, and 3 thematic meaning.

a. Conceptual Meaning

Based on the research finding, the researcher found 17 conceptual meanings, They are:

1) What do I know about Germany? (01/00.15/CONS)

The context was the interviewer asked about what the interviewee knew about Germany. After that, the interviewee wondered the answer by saying "What do I know about Germany?".

It is conceptual meaning because the word 'Germany' means the name of country. 


\section{2) Germany? (05/00.27/CONS)}

The context was the interviewer asked about what the interviewee knew about Germany. After that, the interviewee wondered the answer by saying "Germany?".

It is conceptual meaning because the word 'Germany' means the name of country.

3) but I have heard it's a very nice place to visit, holidays and things, (07/00.31/CONS)

The context was the interviewer asked about what the interviewee knew about Germany. After that, the interviewee answered it by saying "but I have heard it's a very nice place to visit, holidays and things."

It is conceptual meaning because the word 'holidays' means the vacation. It means that Germany is very nice place to visit, holidays, and etc.

4) Very little. I know very little about Germany. (13/00.51/CONS)

The context was the interviewer asked about what the interviewee knew about Germany. After that, the interviewee answered it by saying "Very little. I know very little about Germany."

It is conceptual meaning because the word 'Germany' means the name of country. The utterance means that he did not know about Germany, the name of country.

\section{5) What I know about Germany is .... (17/01.07/CONS)}

The context was the interviewer asked about what the interviewee knew about Germany. After that, the interviewee wondered the answer by saying "What I know about Germany is ...".

It is conceptual meaning because the word 'Germany' means the name of country. The utterance means that he was thinking to find the best describe about Germany.

\section{6) I've been to Munich. (22/01.25/CONS)}

The context was the interviewer asked about what the interviewee knew about Germany. After that, the interviewee answered it by saying "I've been to Munich".

It is conceptual meaning because the word 'Munich' means the name of city in Germany. The utterance means that she has never been in Munich, the one of cities in Germany.

7) Angela, what do you know about Germany? (24/01.29/CONS)

The context was the interviewer asked about what the interviewee knew about Germany. After that, the interviewee asked her friend by saying "Angela, what do you know about Germany. '

It is conceptual meaning because the word 'Germany' means the name of country. The utterance means that she asked her friend, Angela about Germany.

8) We were reading in the news recently about the beer festival in Munich, but that lots of - lots of English and $-(29 / 01.47 / \mathrm{CONS})$
The context was the interviewer asked about what the interviewee knew about Germany. After that, the interviewee told to interviewer by saying "We were reading in the news recently about the beer festival in Munich, but that lots of - lots of English and -"

It is conceptual meaning because the word 'reading' means the cognitive process of decoding symbols to derive meaning. The utterance means that they have been reading the news about beer festival in Munich.

\section{9) Sausages. (34/02.18/CONS)}

The context was the interviewer asked about what the interviewee thought if the interviewee heard the word 'Germany'. After that, the interviewee answered it by saying "Sausages."

It is conceptual meaning because the word 'sausages' means the name of food. Sausages is the name of food which is a cylindrical meat product usually made from ground meat, often pork, beef or veal, along with salt, spices and other flavourings, and breadcrumbs, with a skin around it.

\section{0) Well, I think of the war, (36/02.23/CONS)}

The context was the interviewer asked about Germany to the interviewee. After that, the interviewee answered it by saying "Well, I think of the war."

It is conceptual meaning because the word 'war' means the conflict. The word "War" means a state of armed conflict between societies. It is generally characterized by extreme aggression, destruction, and mortality, using regular or irregular military forces.

11) I think of the 1966 World Cup (37/02.25/CONS) The context was the interviewer asked about what the interviewee knew about Germany. After that, the interviewee answered it by saying "I think of the 1966 World Cup."

It is conceptual meaning because the word 'World Cup' means the name of world football competition. In this utterance, he thought World Cup in 1966 which England managed to defeat West Germany in Final.

\section{Connotative Meaning}

Based on the research finding, the researcher found 8 connotative meanings. They are:

1) It's a big army base. (02/00.18/CONN)

The context was the interviewer asked about what the interviewee thought about Germany. After that, the interviewee answered it by saying "It's a big army base."

The word 'army base' is connotative. It is the a facility directly owned and operated by military. It provides accommodations for units, also be used as a command center, a training ground, and proving ground.

2) British forces are based there. (03/00.20/CONN) The context was the interviewer asked about what the interviewee thought about Germany. After that, the interviewee answered it by saying "British forces are based there." 
The word "Forces"' was not refered to the part of Newton Law in physics, but it was the movement of war in order to attacking and defending states.

3) Now when you go on holiday all the Germans always pinch the deckchairs. (19/01.13/CONN)

The context was the interviewer asked about what the interviewee thought about Germany. After that, the interviewee answered it by saying "Now when you go on holiday all the Germans always pinch the deckchairs."

The word 'Pinch' did not mean pressing something, especially someone's skin, strongly between two hard thing such as a finger and a thumb, but in this utterances, word "Pinch" means setting up or using deckchairs.

4) We knocked it down but they made a better job at building it up again, didin't they? (32/02.08/CONN)

The context was the interviewer asked about what the interviewee thought about Germany. After that, the interviewee answered it by saying "We knocked it down but they made a better job at building it up again, didin't they?"

The word 'Knocked it down' meant that Britain ever defeated Germany in second world wars.

\section{Social Meaning}

Based on the research finding, the researcher found 2 social meanings. They are:

1) I thought it was very good, aye, it's well, it was all rebuilt after the war, wasn't it? (31/02.02/SOC)

The context was the interviewer asked about what the interviewee thought about Germany. After that, the interviewee answered it by saying "I thought it was very good, aye, it's well, it was all rebuilt after the war, wasn't it?"

The word 'Aye' is the slang word which means 'Yes' Origin of 'Aye' is from Middle English. So, the word can indicate that the speaker is older person.

\section{2) $\quad$ Yeh (38/02.29/SOC)}

The context was the interviewer asked about what the interviewee if the 1966 World Cup was the good one. After that, the interviewee answered it by saying "Yeh". The word 'Yeh' is the slang word which meant 'Yes'. This word is used in casual conversation and informal situation.

\section{Affective Meaning}

Based on the research finding, the researcher found 19 affective meaning. They are:

1) It's not a place that I've ever been to, (06/00.28/AFF)

The context was the interviewer asked about what the interviewee knew about Germany. After that, the interviewee answered it by saying "It's not a place that I've ever been to, "

In the utterance, she told that she had ever been Germany and sounded weird to be asked about Germany.

2) but otherwise not really a place I know much about, to be honest with you. (08/00.35/AFF)
The context was the interviewer asked about what the interviewee thought about Germany. After that, the interviewee answered it by saying "but otherwise not really a place I know much about, to be honest with you."

In the utterance, she told that she did not quite know about Germany and thought that sounded weird to be asked about Germany.

\section{3) Not to much (10/00.41/AFF)}

The context was the interviewer asked about what the interviewee thought about Germany. After that, the interviewee answered it by saying "Not to much. "In the utterance, he told that he did not know much about Germany and deny what interviewer expected about him to be asked about Germany.

4) It's very wealthy isn't it? And we're the poor men of Europe now. (11/00.42/AFF)

The context was the interviewer asked about what the interviewee thought about Germany. After that, the interviewee answered it by saying "It's very wealthy isn't it? And we're the poor men of Europe now. "

She praised Germany as the wealthier than her country, England. She thought Germany always be greater than England.

5) You've just re-elected Angela Merkel, haven't you? And, (12/00.47/AFF)

The context was the interviewer asked about what the interviewee thought about Germany. After that, the interviewee answered it by saying "You've just re-elected Angela Merkel, haven't you? And, '

In the utterance, she said that German people had reelected Angela Merkel as leader voices of Germany and thought that Germany will keep greater than England.

\section{6) No. (14/00.58/AFF)}

The context was the interviewer asked about what the interviewee thought about Germany. After that, the interviewee answered it by saying "No."

In the utterance, he expressed that he did not know about Germany.

\section{7) Sorry (15/00.59/AFF)}

The context was the interviewer asked if the interviewee really didn't know about Germany. After that, the interviewee answered it again by saying "Sorry."

In the utterance, he expressed his apologizing about his guilty feeling not able to answer and thought if the interviewer better find the others to answer.

8) They're better than us at football and that's about it! (16/01.01/AFF)

The context was the interviewer asked about what the interviewee thought about Germany. After that, the interviewee answered it by saying "They're better than us at football and that's about it!"

In the utterance, he said that Germany football team is better than England's. 
9) They always come out and put their towels down first. Before you get down there. (20/01.17/AFF)

The context was the interviewer asked about what the interviewee thought about Germany. After that, the interviewee answered it by saying "They always come out and put their towels down first. Before you get down there."

In the utterance, he mentioned one thing that mostly done by German people which always put towels down first on deckchairs before they get down there. It is like what only german people do that.

\section{0) To be honest, I quite like Germany! (39/02.30/AFF)}

The context was the interviewer asked about what the interviewee thought about Germany. After that, the interviewee answered it by saying "To be honest, I quite like Germany!"’

In the utterance, he expressed his liking to Germany and told that interviewer was good to ask him about that question.

11) I think we all descend from the same sort of Anglo-Saxon race, so yeah, no problem with that. (43/02.39/AFF)

The context was the interviewer asked about what the interviewee thought about relation Germany and England. After that, the interviewee answered it by saying "I think we all descend from the same sort of Anglo-Saxon race, so yeah, no problem with that."

In the utterance, he thought that was no problem either German people and British, because both were descended from the same sort of Anglo-Saxon and had to be peace.

12) I can't afford, I can't deny that. (51/03.21/AFF) The context was the interviewer asked about what the interviewee thought about BMW, Marcedes and Audis. After that, the interviewee answered it by saying "I can't afford, I can't deny that. "

In the utterance, he could not deny that BMW, Marcedes, and Audis are good car from Germany

\section{Reflected Meaning}

Based on the research finding, the researcher found 5 reflected meanings. They are:

\section{1) Stella? (18/01.08/REFL)}

The context was the interviewer asked about what the interviewee thought about Germany. After that, the interviewee answered it by saying "Stella"

She told something ambiguously about 'Stella'. Because the answer did not have correlation to question. She perhaps mentioned the one of Belgian beer, Stella Artois.

\section{2) The Oktoberfest? (25/01.33/REFL)}

The context was the interviewer asked about what the interviewee thought about Germany. After that, the interviewee answered it by saying "The Oktoberfest?" The Oktoberfest is the world's most famous beer festival, taking place in the German city of Munich.
3) No, didn't get really drunk. (27/01.38/REFL)

The context was the interviewer asked about if the interviewee ever got really drunk. After that, the interviewee answered it by saying "No, didn't get really drunk"

The word 'Drunk' in this utterance meant a temporary state in which one's physical and mental faculties are impaired by an excess of alcoholic drink.

\section{Collocative Meaning}

. Based on the research finding, the researcher found 5 collocative meanings. They are:

1) It's pretty (23/01.26/COLL)

The context was the interviewer asked about what the interviewee thought about Germany. After that, the interviewee answered it by saying "It's pretty."

The word "Pretty" is mostly used for woman, but in this utterance, it was used for explaining something that is good.

2) I took it easy (28/01.40/COLL)

The context was the interviewer asked about the interviewee's experiences joined The Oktoberfest. After that, the interviewee answered it by saying "I took it easy."

The word 'Easy' in this utterance meant something that was little, or not too much.

3) I must admit the Mercedes and BMWs and Audis are brilliant cars! (50/03.18/COLL)

The context was the interviewer asked about what the interviewee thought about Germany. After that, the interviewee answered it by saying "I must admit the Mercedes and BMWs and Audis are brilliant cars!"

In the utterance, the word 'Brilliant' in this utterance meant something that was good and luxurious.

\section{Thematic Meaning}

Based on the research finding, the researcher found 6 thematic meanings. They are:

\section{1) That's it. (04/00.26/THEM)}

The context was the interviewer asked about what the interviewee thought about Germany. After that, the interviewee stated at the end of his answer by saying "That's it"

It meant that what he knew about Germany was having a big army base and British forces are based in Germany.

2) That's what I know. (21/01.21/THEM)

The context was the interviewer asked about what the interviewee thought about Germany. After that, the interviewee stated at the end of his answer by saying "That's what I know."

It meant that what the interviewee knew about Germany was Germans always pinch the deckchairs, and put their towels down first before using deckchairs.

\section{3) Yeh, I have (26/01.36/THEM)}

The context was the interviewer asked if the interviewee ever joined The Oktoberfest. After that, the interviewee answered it by saying "Yeh, I have" 
It meant that the interviewee had ever been in Oktoberfest.

\section{CONCLUSION}

Based on the research finding and discussion, the researcher would like to make some conclusions as follow:

In this research, the researcher focused on the meaning types as Leech's theory which was found in interviewee's utterances of Easy English video: What Do You Know About Germany episode. The Meaning Types That Were Found in the Easy English Video.The researcher found 62 data in Easy English video which are consist of several types, they are 17 conceptual meanings, 8 connotative meanings, 2 social meanings, 19 affective meanings, 5 reflected meanings, 5 collocative meanings, and 6 thematic meanings.

\section{ACKNOWLEDGEMENT}

We want to say thank you for the ones who participate in doing this research, and also for our students in Veteran Bangun Nusantara University.

\section{REFERENCES}

[1] Carstairs, Andrew. An Introduction to English Morphology: Words and Their Structure. Great Britain: Edinburgh University Press. 2002

[2] Fauziati, Endang. Psycholinguistic An Introduction. Surakarta: Era Pustaka Utama. 2011

[3] Tarigan, Henry Guntur. Pengajaran Semantik. Bandung: Angkasa 2009

[4] Leech, Geoffrey. Semantics : The Study of Meaning https://yanjianghk.files.wordpress.com/2014/09/geoffrey_leech_sema ntics_the_study_of_meaning.pdf (accessed May $3^{\text {rd }}$ 2017) 1981

[5] Umagandhi and Vinothini. Leech's Seven Types of Meaning in Semantics. International Journal of Multidiciplinary Research and Development. Vol. IV, Issue 3, March 2017. (71-72) http://www.allsubjectjournal.com/download/2903/4-2-30 (accessed May $8^{\text {th }}$ 2017). 2017.
[6] Sugiyono. Metode Penelitian Kuantitatif, Kualitatif dan R\&D. Bandung: Alfabeta. 2008

[7] Achmad HP and Abdullah, Alek. Linguistik Umum. Jakarta: Penerbit Erlangga, 2012.

[8] Chaer, Abdul. Pengantar Semantik Bahasa Indonesia. Jakarta: Rineka Cipta. 2010. Sosiolinguistik: Perkenalan Awal. Jakarta: Rineka Cipta. 2009

[9] Holmes, Janet. An Intrduction to Sociolinguistcs, Second Edition. England: Pearson Education. 2001

[10] Kasihani and Rahmajanti, Sri. Let's Communicate in English, Book 3. Malang: Bayumedia Publisher. 2003

[11] Moleong J Lexy.. Metodologi Penelitian Kualitatif. Bandung: PT. Remaja Rosdakarya. 2010

[12] Ullman, Stephen. Pengantar Semantik. Yogyakarta: Pustaka Belajar. 2007

[13] Yule, George. Kajian Bahasa (Edisi Kelima). Yogyakarta: Pustaka Pelajar. 2015

[14] Moreno, Daniela.. The Importance of Semantics in Language Teaching. Universidad Autonoma de Nuevo Leon Facultad de Filosofia $y$ Letras Ciencias del Lenguaje. May $20^{\text {th }} 2015$. http://www.academia.edu/17447801/The importance of semantics i n language teaching (accessed June $9^{\text {th }} 2017$ ). 2015

[15] Muttaqien, Zaenal. The Denotative and Connotative Meanings in the AXE Adverstisements. Jakarta: Syarief Hidayatullah State Islamic University.

http://repository.uinjkt.ac.id/dspace/bitstream/123456789/535/1/1019 55-ZAENAL\%20MUTTAQIEN-FAH.pdf (accessed June $9^{\text {th }} 2017$ ). 2011.

[16] Sri, Nanik Rahayu. Desain Multimedia. http://ftp.unpad.ac.id/bse/Kurikulum_2013/Kelas_11_SMK_Desain_ Multimedia_1.pdf (accessed May $8^{\text {th }}$ 2017). 2013

[17] Sunaga, Minako. A Study of Interviews: The Roles of Interviewer and Interviewee. Proceeding of The $8^{\text {th }}$ Conference of Pan-Pacific Association of Applied Linguistics. August $4^{\text {th }}-5^{\text {th }}, 2003$. http://www.paaljapan.org/resources/proceedings/PAAL8/pdf/pdf038. pdf $\quad$ (accessed $\quad$ September $\left.\quad 6^{\text {th }} \quad 2017\right) 2003$ 